ISSN: $1412-8837$

\title{
ANALISIS EFISIENSI DAN PENDAPATAN USAHA PEMBIBITAN KARET PADA PTPN III KEBUN RAMBUTAN TEBING TINGGI, SUMATERA UTARA
}

\author{
Muhamad Nurung \\ Jurusan Sosial Ekonomi Pertanian \\ Fakultas Pertanian Universitas Bengkulu
}

\begin{abstract}
The objective of this research was to know the number of income and level of efficiency in rubbers seeding business at PTPN III Kebun Rambutan. This research was done in five rubber seeding blocks in PTPN III Kebun Rambutan. PTPN III Kebun Rambutan was chosen as the place of the research because this company was the only one company that sold its rubber seeds to local consumers. The results of this research was shown that the average of real $R / C$ Ratio was 1,81 and the unreal was 1,85 the meaning was efficient. The average of PTPN III Kebun Rambutan real income was Rp 1.166.509.090,93/Ut/5 months and the unreal income was $R p$ 1.221.160.530,93/Ut/5 months. It means that PTPN III has been success in doing its business.
\end{abstract}

Key words: income analysis, efficiency analysis

\section{PENDAHULUAN}

Pembangunan sektor pertanian perlu mendapat perhatian serius dari pemerintah terutama dalam mengembangkan potensi komoditas perkebunan. Hal ini disebabkan karena subsektor perkebunan telah mampu memberikan kontribusi nilai ekspor yang cukup besar terutama dari ekport karet alam (Hevea brassiliensis). Perkebunan karet alam telah menjadi sumber penghasil devisa, maupun sumber penghidupan dan pendapatan masyarakat petani. Karet alam telah menjadi komoditi andalan penghasil devisa kelima setelah minyak bumi, kayu, tekstil dan pariwisata. Padahal baru tahun 1864 perkebunan karet mulai diperkenalkan di Indonesia yaitu di daerah Pamanukan dan Ciasem Jawa Barat serta di Sumatera Utara pada tahun 1906 (Semangun, 2000).

Karet sebagai bahan baku utama pembuatan lateks pekat maupun crumb rubber merupakan salah satu produk yang banyak diminati oleh para investor karena memiliki nilai ekonomis yang tinggi. Banyaknya investor yang mengembangkan bisnis karet telah menciptakan kesempatan kerja yang mengarah pada peningkatan kesejahteraan masyarakat (Anonim, 2008). Getah pohon karet

24 | Muhamad Nurung. Analisis Efisiensi dan Pendapatan Usaha Pembibitan Karet 
sangat berharga, apalagi dengan adanya teknologi yang mampu mengubahnya menjadi beraneka ragam barang industri. Hingga saat ini industri ban kendaraan bermotor merupakan konsumen karet alam terbesar (menyerap 70\% bahan baku).

PTPN III Kebun Rambutan merupakan salah satu perusahaan yang bergerak dalam pengembangan agroindustri karet dan telah memberikan kontribusi dalam devisa negara. PTPN III ini juga mengelola beberapa komoditi lainnya yang memiliki nilai ekonomis tinggi. Menurut data pada tahun 2007, tanaman unggulan PTPN III terdiri dari kelapa sawit, karet, dan kakao dengan luas lahan untuk komoditi kelapa sawit $98.690,14$ ha, komoditi karet $54.477,80$ ha, dan komoditi kakao 8.761 ha.

Langkah awal dalam usahatani karet yang baik adalah menggunakan bibit karet yang berkualitas sehingga mampu menghasilkan lateks yang tinggi. Hal inilah yang menyebabkan PTPN III berupaya untuk mengembangkan usaha pembibitan karet klon unggul. Upaya tersebut didukung oleh tersedianya lahan untuk tanaman karet yang cukup luas. Langkah tersebut dilakukan dengan tujuan untuk mendukung kegiatan produksi dan kebutuhan pasar terhadap bibit tanaman karet (Sihombing, 2008).

Mengingat pentingnya bibit dalam pengembangan perkebunan karet, maka usaha pembibitan perlu dikelola secara baik dan benar. Pengelolaan usaha pembibitan karet perlu menggunakan bibit-bibit yang berkualitas yang berasal dari klon-klon baru serta manajemen yang profesional. Pengelolaan usaha yang profesional ditandai oleh adanya efisiensi dan pendapatan yang diperoleh cukup besar. Oleh karena itu yang menjadi tujuan penelitian ini adalah; mengetahui kondisi efisiensi dan menghitung besar pendapatan usaha pembibitan karet di unit afdeling pembibitan PTPN III Kebun Rambutan.

\section{METODE PENELITIAN}

Penelitian ini dilakukan pada lokasi usaha pembibitan karet perusahaan PTPN III Kebun Rambutan Sumatera Utara. Pemilihan lokasi secara sengaja (purposive) karena perusahaan tersebut merupakan salah satu unit usaha terbesar dalam menghasilkan dan mendistribusikan bibit karet kepada petani. Disamping itu pengelolaan usaha pembibitan karet dilakukan dalam skala besar yakni mencapai 1500 hektar yang dibagi atas 5 blok. 
Data yang dikumpulkan dalam penelitian ini adalah data sekunder yang berhubungan dengaan usaha pembibitan karet misalnya luas lahan, biaya penggunaan pupuk, biaya tenaga kerja, biaya pestisida, produksi, penerimaan dan pendapatan. Pengumpulan data menggunakan metode studi pustaka (library research) dan penelitian lapangan (field research).

Analisis biaya digunakan untuk mengetahui seluruh biaya yang dikeluarkan dalam usaha pembibitan karet. Biaya-biaya yang dikeluarkan oleh perusahaan dalam usaha pembibitan karet dapat dihitung dengan menggunakan rumus sebagai berikut (Soekartawi, 2004) :

$$
\mathrm{TC}=\mathrm{TFC}+\mathrm{TVC}
$$

Dimana: $\mathrm{TC}=$ Biaya total / Total Cost $(\mathrm{Rp} / 5$ bulan $)$

$\mathrm{TFC}=$ Biaya tetap total $/$ Fixed Cost $(\mathrm{Rp} / 5$ bulan $)$

TVC $=$ Biaya variabel total $/$ Variable Cost $(\mathrm{Rp} / 5$ bulan $)$

Untuk mengetahui tingkat penerimaan atau hasil penjualan usaha pembibitan karet digunakan persamaan sebagai berikut (Soekartawi, 2004) :

$$
\mathbf{T R}=\mathbf{Y} \text {. Py }
$$

Dimana $: \mathrm{TR}=$ Total Revenue atau total penerimaan $(\mathrm{Rp} / 5$ bulan $)$

$\mathrm{Y}=$ Jumlah produksi yang diperoleh (Batang)

Py $=$ Harga produksi $(\mathrm{Rp})$

Analisis efisiensi dilakukan untuk mengetahui apakah usaha pembibitan karet telah efisien, tidak efisien atau belum efisien, maka dapat digunakan rumus sebagai berikut (Soekartawi, 2004) :

$$
\begin{array}{ll}
\text { R/C Ratio }= & \text { Total Revenue }(\mathrm{TR}) \\
\text { Dimana : } & \begin{array}{l}
\text { Total Cost }(\mathrm{TC}) \\
\mathrm{TR}=\text { Total Revenue } / \text { Penerimaan }(\mathrm{Rp} / 5 \text { bulan })
\end{array} \\
& \mathrm{TC}=\text { Total Cost } / \text { Total biaya }(\mathrm{Rp} / 5 \text { bulan })
\end{array}
$$

Dengan kriteria :

1. Jika nilai $\mathrm{R} / \mathrm{C}$ Ratio $<1$, maka usaha pembibitan karet yang dilaksanakan oleh PTPN III Kebun Rambutan tidak efisien.

2. Jika nilai R/C Ratio >1, maka usaha pembibitan karet yang dilaksanakan oleh PTPN III Kebun Rambutan telah efisien. 
3. Jika nilai $\mathrm{R} / \mathrm{C}$ Ratio $=1$, maka usaha pembibitan karet yang dilaksanakan oleh PTPN III Kebun Rambutan belum efisien karena tidak menguntungkan.

Analisis pendapatan dilakukan untuk menghitung seberapa besar pendapatan yang diperoleh dari usaha pembibitan karet. Tingkat pendapatan ini dihitung dengan menggunakan rumus sebagai berikut (Soekartawi, 2004) :

$$
\mathbf{I}=\mathbf{T R}-\mathbf{T C}
$$

Dimana: I = Income / Pendapatan $(\mathrm{Rp} / 5$ bulan $)$

$\mathrm{TR}=$ Total Revenue $/$ Penerimaan Total $(\mathrm{Rp} / 5$ bulan $)$

$\mathrm{TC}=$ Total Cost $/$ Biaya Total $(\mathrm{Rp} / 5$ bulan $)$

\section{Luas lahan Usaha Pembibitan Karet}

HASIL DAN PEMBAHASAN

Gambaran tentang luas lahan usaha pembibitan dapat dilihat pada Tabel 1.

Tabel 1. Luas lahan setiap Afdeling (blok) Pembibitan PTPN III Kebun Rambutan

\begin{tabular}{llllll}
\hline & \multirow{2}{*}{ Blok } & $\begin{array}{c}\text { Tipe } \\
\text { Field }\end{array}$ & Luas Lahan (Ha) & \multicolumn{2}{c}{ Klon (Biji) Unggul } \\
\cline { 5 - 6 } & I & $81 \mathrm{~A} / 82 \mathrm{~F}$ & 310 & Batang Atas & Batang Bawah \\
\hline II & $82 \mathrm{M} / 84 \mathrm{C}$ & 290 & PB-260 & AVROS-2037 \\
& III & $83 \mathrm{D}$ & 300 & PB-260 & AVROS-2037 \\
& IV & $84 \mathrm{D} / 84 \mathrm{E}$ & 280 & PB-260 & AVROS-2037 \\
& V & $85 \mathrm{~F}$ & 320 & PB-260 & AVROS-2037 \\
\hline Jumlah & 5 & & 1500 & & \\
Rata-rata & 1 & & 300 & & \\
\hline
\end{tabular}

Sumber : Pengolahan Data Sekunder, 2008

Berdasarkan Tabel 1 diketahui bahwa bibit yang dipelihara berasal dari klon unggul. Bibit tersebut dikelola pada lima blok seluas 1500 hektar yang kemudian dijadikan tempat usaha pembibitan karet. Hal ini berarti usaha yang dikelola sudah tergolong skala besar. Lokasi lahan sebesar itu tentunya hanya dapat dilakukan oleh para investor yang memiliki dana cukup besar pula.

\section{Biaya Produksi Usaha Pembibitan Karet}

Biaya produksi disini adalah seluruh biaya yang dikeluarkan untuk memproduksi bibit karet. Rata-rata biaya produksi yang digunakan dapat dilihat pada Tabel 2. Dari tabel tersebut diketahui bahwa rata-rata biaya untuk membeli 
biji karet unggul (PB-260 dan AVROS-2037) adalah sebesar Rp 597.945.000/Ut/5 bln atau sebesar Rp 1.990.328/Ha/5 bln.

Pupuk merupakan suatu material organik maupun anorganik yang sudah diproses secara alamiah maupun buatan yang dapat memberikan pengaruh terhadap tanaman. Dalam melakukan pemupukan, PTPN III Kebun Rambutan menggunakan pupuk Urea, TSP, dan $\mathrm{KCl}$. Ketiga jenis pupuk ini digunakan karena mengandung unsur Fospat $(\mathrm{P})$, Nitrogen $(\mathrm{N})$, dan Kalium $(\mathrm{K})$ yang dibutuhkan tanaman karet. Pemupukan dilakukan sebanyak dua kali dalam satu tahun. Ratarata biaya untuk pembelian pupuk adalah sebesar Rp 111.641.668,19/Ut/5 bln atau Rp 371.441,70/Ha/5 bln.

Pestisida merupakan bahan kimia yang digunakan untuk mengendalikan hama dan penyakit tanaman. Besar kecilnya biaya pestisida yang dikeuarkan tergantung dari tingkat berat serangan hama dan penyakit tanaman. Jenis pestisida yang digunakan oleh PTPN III Kebun Rambutan ada 3 jenis, yaitu Furadan, Roundup dan Lindomin. Furadan merupakan pestisida yang berbentuk butiran (granular), sedangkan Roundup dan Lindomin merupakan pestisida yang berbentuk cair (liquid). Rata-rata biaya yang dikeluarkan sebesar Rp 198.143.004,08/Ut/5 bln atau $\mathrm{Rp} 659.576,33 / \mathrm{Ha} / 5$ bln.

Besar kecilnya tingkat upah yang dibayar kepada para buruh lepas yang bekerja pada bagian pembibitan di PTPN III Kebun Rambutan yakni mulai dari Rp 30.000 hingga Rp 35.000 sesuai dengan jenis pekerjaan yang dilakukan. Rata-rata biaya yang dikeluarkan untuk pembayaran upah buruh lepas dalam usaha pembibitan karet sebesar Rp22.260.000/Ut/5 bln atau Rp 74.149,64/Ha/5 bln.

Polybag merupakan wadah yang terbuat dari bahan plastik yang berbentuk tabung dengan diameter yang berbeda-beda dan digunakan sebagai tempat menanam tanaman. Dalam usaha pembibitan karet, PTPN III Kebun Rambutan mengeluarkan biaya untuk pembelian polybag rata-rata sebesar Rp 31.018.100/Ut/5 bln atau sebesar Rp 103.283/Ha/5 bln.

Dalam melakukan usaha pembibitan karet, PTPN III Kebun Rambutan menggunakan peralatan pertanian untuk mendukung kegiatan tersebut. Peralatanperalatan tersebut tidak habis dipakai dalam satu kali produksi, oleh karena itu nilai penyusutannya dihitung sebagai biaya. Biaya penyusutan adalah nilai awal dikurangi dengan nilai akhir dan dibagi dengan umur ekonomis kemudian dikalikan dengan jumlah peralatan dengan asumsi bahwa harga akhir peralatan 
yang dipakai adalah nol. Dari Tabel 2 diketahui bahwa rata-rata biaya penyusutan peralatan yang dikeluarkan oleh PTPN III Kebun Rambutan adalah sebesar Rp 330.795.496,81/Ut/5 bln atau sebesar Rp 1.128.987,36/Ha/5 bln.

Tabel 2. Rata-rata Biaya Produksi Afdeling Pembibitan PTPN III Kebun Rambutan

\begin{tabular}{|c|c|c|}
\hline Jenis Biaya & $\begin{array}{c}\text { Rata-rata Biaya } \\
\text { (Rp/Ut/5 bln) }\end{array}$ & $\begin{array}{c}\text { Rata-rata Biaya } \\
\text { (Rp/Ha/5 bln) }\end{array}$ \\
\hline \multicolumn{3}{|l|}{ * Biaya Variabel } \\
\hline \multicolumn{3}{|l|}{ 1. Biaya biji karet unggul } \\
\hline a. PB-260 & 295.405 .000 & $983.303,00$ \\
\hline b. AVROS-2037 & 302.540 .000 & $1.007 .024,00$ \\
\hline Jumlah & 597.945 .000 & $1.990 .328,00$ \\
\hline \multicolumn{3}{|l|}{ 2. Biaya pupuk } \\
\hline a. Urea & $30.687 .734,74$ & $102.120,94$ \\
\hline b. TSP & $67.802 .461,77$ & $225.567,11$ \\
\hline c. $\mathrm{KCl}$ & $13.151 .471,68$ & $43.753,65$ \\
\hline Jumlah & $111.641 .668,19$ & $371.441,70$ \\
\hline \multicolumn{3}{|l|}{ 3. Biaya pestisida } \\
\hline a. Furadan & 95.118 .750 & $316.649,96$ \\
\hline b. Roundup & $81.715 .462,10$ & $272.027,64$ \\
\hline c. Lindomin & $21.308 .791,98$ & $70.898,73$ \\
\hline Jumlah & $198.143 .004,08$ & $659.576,33$ \\
\hline 4. Biaya tenaga kerja & 22.260 .000 & $74.149,64$ \\
\hline 5. Biaya polybag & 31.018 .10 & $103.283,00$ \\
\hline 6. Biaya bahan bakar & 35.215 .600 & $117.751,64$ \\
\hline \multicolumn{3}{|l|}{ * Biaya Tetap } \\
\hline 1. Biaya penyusutan alat & $330.795 .496,81$ & $1.128 .987,36$ \\
\hline 2. Biaya listrik & 9.948 .600 & $33.235,97$ \\
\hline 3. Biaya telepon & 4.655 .600 & $15.553,28$ \\
\hline 4. Biaya gaji \& tunjangan staf tetap & 37.374 .400 & $124.859,23$ \\
\hline 5. Biaya umum & 59.055 .900 & $197.160,66$ \\
\hline Jumlah & $1.438 .053 .369,07$ & $4.816 .326,32$ \\
\hline
\end{tabular}

Sumber : Pengolahan Data Sekunder, 2008

Bahan bakar merupakan salah satu pendukung dalam pengelolaan usaha pembibitan karet. Dari hasil penelitian diketahui bahwa bahan bakar yang digunakan oleh PTPN III Kebun Rambutan berupa solar dan pelumas. Rata-rata 
ISSN: $1412-8837$

biaya bahan bakar yang dikeluarkan untuk usaha pembibitan karet sebesar Rp 35.215.600/Ut/5 bln atau sebesar Rp 117.751,64/Ha/5 bln.

Listrik merupakan salah satu komponen yang juga turut mendukung berlangsungnya kegiatan pembibitan. Berdasarkan hasil penelitian, rata-rata biaya listrik yang dikeluarkan dalam pengelolaan usaha pembibitan karet sebesar Rp 9.948.600/Ut/5 bln atau sebesar Rp33.235,97/Ha/5 bln.

Dari Tabel 2 dapat dilihat bahwa dalam usaha pembibitan karet, biaya telepon yang dikeluarkan oleh PTPN III Kebun Rambutan sebesar Rp 4.655.600/Ut/5 bln atau sebesar $\operatorname{Rp} 15.553,28 / \mathrm{Ha} / 5$ bln. Penggunaan sarana ini ditujukan untuk memudahkan komonikasi internal dan ekternal perusahaan dalam kegiatan pengelolaan usaha pembibitan karet.

Karyawan tetap/staff merupakan tenaga kerja yang digaji dengan menggunakan gaji tetap yang jumlahnya sama untuk setiap bulan dan menerima tunjangan. Dari Tabel 2, diketahui bahwa biaya yang dkeluarkan oleh PTPN III Kebun Rambutan untuk pembayaran gaji dan tunjangan staff sebesar Rp 37.374.400/Ut/5bln atau sebesar Rp 124.859,23/Ha/5bln.

Biaya umum merupakan biaya yang meliputi biaya administrasi, asuransi, penelitian, dan perawatan mesin dan instalasi. Admnistrasi ditujukan untuk menjaga kelancaran usaha pembibitan, sedangkan asuransi ditujukan untuk melindungi dan menjamin para karyawan sehingga para karyawan merasa aman dalam bekerja. Dan untuk tetap menjaga bibit yang diproduksi berkualitas, PTPN III Kebun Rambutan melakukan penelitian sehingga diharapkan konsumen akan puas terhadap bibit yang dibeli. Berdasarkan hasil penelitian, rata-rata biaya yang dikeluarkan oleh PTPN III Kebun Rambutan sebesar Rp 59.055.900/Ut/5bln atau sebesar Rp 197.160,66.

\section{Produksi}

Produksi yang dimaksud dalam penelitian ini adalah bibit karet yang dihasilkan oleh PTPN III Kebun Rambutan dalam satu kali proses produksi yang dihitung dalam satuan batang. Produksi yang dihasilkan oleh PTPN III Kebun Rambutan dapat dilihat pada Tabel 3 berikut :

30 | Muhamad Nurung. Analisis Efisiensi dan Pendapatan Usaha Pembibitan Karet 
ISSN: $1412-8837$

Tabel 3. Produksi Usaha Pembibitan Karet di Afdeling Pembibitan PTPN III Kebun Rambutan

\begin{tabular}{lccccc}
\hline Keterangan & \multicolumn{5}{c}{ Produksi } \\
\cline { 2 - 6 } & Bibit mati & $\begin{array}{c}\text { Bibit } \\
\text { tumbuh }\end{array}$ & Bibit rusak & $\begin{array}{c}\text { Bibit layak } \\
\text { jual } \\
(\text { Batang) }\end{array}$ & $\begin{array}{c}\text { Total } \\
\text { produksi } \\
\text { (Batang) }\end{array}$ \\
\hline Rata-rata & 215 & 711807 & 184 & 711623 & 712022 \\
\hline
\end{tabular}

Sumber : Pengolahan Data Sekunder, 2008

Tabel 3 menunjukkan bahwa rata-rata produksi bibit karet yang dihasilkan oleh PTPN III Kebun Rambutan sebanyak 712022 batang, dengan rata-rata bibit yang layak untuk dijual sebanyak 711623 batang. Besar kecilnya produksi dipengaruhi oleh penggunaan faktor produksi seperti pupuk, pestisida, cuaca, luas tanam, tingkat kesuburan tanah, dan perawatan tanaman yang dilakukan. Bibit yang yang rusak jumlahnya tergolong kecil dibandingkan dengan jumlah bibit yang dapat dijual sehingga usaha ini tergolong sukses dalam melakukan proses produksi

\section{Penerimaan}

Penerimaan usaha pembibitan karet merupakan merupakan hasil perkalian antara bibit karet yang dihasilkan dengan harga jual. Harga jual bibit karet bervariasi mulai dari Rp 3.300 hingga Rp 3.900. Rata-rata penerimaan yang diterima oleh PTPN III Kebun Rambutan dari setiap blok pembibitan dapat dilihat pada Tabel 4.

Tabel 4. Penerimaan Riil dan Non Riil Usaha Pembibitan Karet pada PTPN III Kebun Rambutan

\begin{tabular}{lcccc}
\hline \multirow{2}{*}{ Keterangan } & \multicolumn{2}{c}{ Penerimaan Riil } & \multicolumn{2}{c}{ Penerimaan Non Riil } \\
\cline { 2 - 5 } & $\mathbf{( R p / U t / 5 b l n )}$ & $\mathbf{( R p / H a} / 5 b l n)$ & $\mathbf{R p} / \mathrm{Ut} / 5 b l n)$ & $\mathbf{( R p / H a / 5 b l n )}$ \\
\hline Rata-rata & 2.604 .562 .460 & $8.678 .111,21$ & 2.704 .933 .880 & $9.006 .103,27$ \\
\hline
\end{tabular}

Sumber: Pengolahan Data Sekunder, 2008.

Tabel 4 menunjukkan bahwa rata-rata penerimaan riil usaha pembibitan karet PTPN III sebesar Rp 2.604.562.460/Ut/5bln atau sebesar Rp 8.678.111,21/Ha/5bln. Nilai penerimaan riil ini dipengaruhi oleh harga jual bibit dan produksi bibit yang dihasilkan serta penggunaan biji karet unggul (PB-260 dan AVROS-2037) dalam proses produksi sehingga konsumen (petani) tidak ragu untuk membelinya. 
ISSN: $1412-8837$

Penerimaan non riil nilainya jauh lebih besar jika dibanding dengan nilai penerimaan riil. Hal ini disebabkan karena penerimaan non riil merupakan hasil perkalian antara seluruh produksi yang dihasilkan dikalikan dengan harga jual bibit per batang. Sedangkan penerimaan riil diperoleh hanya dari perkalian jumlah produksi yang terjual dengan harga jual bibit per batang.

\section{Efisiensi}

Usaha yang efisien adalah usaha yang dapat mendatangkan keuntungan, dalam hal ini ditandai oleh lebih besarnya penerimaan dibandingkan biaya yang dikeluarkan. Oleh karena itu efisiensi dapat ditentukan melalui perbandingan antara penerimaan dan biaya yang dikeluarkan (R/C Ratio). Nilai R/C Ratio hasil penelitian dapat dilihat pada Tabel 5 .

Tabel 5. Efisiensi Riil dan Non Riil Usaha Pembibitan Karet pada PTPN III Kebun

\begin{tabular}{llcc}
\hline No & & Uraian & R/C Ratio \\
\hline 1. & Riil & 1,81 \\
2. & Non Riil & 1,85 \\
\hline
\end{tabular}

Sumber : Pengolahan Data Sekunder, 2008.

Berdasarkan Tabel 5 dapat dikatakan bahwa usaha pembibitan karet yang dijalankan oleh PTPN III Kebun Rambutan telah dikelola secara efisien karena nilai R/C Ratio >1. Secara riil, dengan nilai R/C Ratio sebesar 1,81 ini menandakan bahwa apabila dalam proses produksi digunakan input (masukan biaya) sebesar Rp 1.000,- maka akan diperoleh penerimaan riil sebesar Rp 1.810,-. Dari segi non riil, usaha pembibitan karet ini juga efisien, karena nilai R/C Ratio sebesar 1,85, berarti apabila menggunakan input sebesar Rp 1.000,- maka akan diperoleh penerimaan non riil sebesar $\operatorname{Rp} 1.850,-$.

Tingkat efisiensi yang diperoleh usaha pembibitan karet ini dipengaruhi oleh produksi yang dihasilkan tergolong berkwalitas karena diproduksi menggunakan biji unggul sehingga konsumen tertarik untuk membeli dengan harga yang tergolong tinggi. Hal ini terlihat dari banyak produksi yang laku terjual. Disamping itu produksi yang dihasilkan cukup banyak karena usaha ini tergolong sukses dalam melakukan proses produksi. Hal ini terlihat sedikitnya produksi yang rusak.

\section{Pendapatan}

32 | Muhamad Nurung. Analisis Efisiensi dan Pendapatan Usaha Pembibitan Karet 
Pendapatan PTPN III Kebun Rambutan diperoleh dengan cara menghitung selisih antara penerimaan dengan biaya total yang dikeluarkan. Data mengenai pendapatan riil dan non riil dari usaha pembibitan karet dapat dilihat pada Tabel 6 . Tabel tersebut menunjukkan; rata-rata penerimaan sebesar Rp 2.604.562.460/Ut/5bln atau sebesar Rp 8.678.111,21/Ha/5bln dan rata-rata biaya sebesar Rp 1.438.053.369,07/Ut/5bln atau sebesar $\mathrm{Rp} 4.816 .326,32 / \mathrm{Ha} / 5 \mathrm{bln}$, sehingga menghasilkan pendapatan riil sebesar Rp 1.166.509.090,93/Ut/5bln atau sebesar Rp 3.861.784,88/Ha/5bln. Pendapatan yang tergolong tinggi ini dipengaruhi oleh suksesnya usaha ini dalam melakukan proses produksi sehingga produksinya cukup banyak dan mampu menjual seluruh produksi tersebut. Kemudian dalam proses produksi biaya yang digunakan jauh lebih rendah dibandingkan dengan nilai hasil penjualan produksi.

Tabel 6. Pendapatan Riil dan Non Rill Usaha Pembibitan Karet pada PTPN III Kebun Rambutan

\begin{tabular}{lccccrr}
\hline \multirow{2}{*}{ Uraian } & \multicolumn{2}{c}{ Penerimaan } & \multicolumn{2}{c}{ Biaya Produksi } & \multicolumn{2}{c}{ Pendapatan } \\
\cline { 2 - 7 } & $\mathbf{R p / U t / 5 b l n}$ & $\mathbf{R p} / H a / 5 b l n$ & Rp/Ut/5bln & Rp/Ha/5bln & $\begin{array}{c}\text { Rp/Ut/5 } \\
\text { bln }\end{array}$ & $\begin{array}{c}\text { Rp/Ha/5 } \\
\text { bln }\end{array}$ \\
\hline Rata-rata & 2.604 .562 .460 & $8.678 .111,21$ & $1.438 .053 .369,07$ & $4.816 .326,32$ & 1.166 .509 .0 & 3.861 .784$, \\
Riil & & & & & 90,93 & 88 \\
Rata-rata & 2.704 .933 .880 & $9.006 .103,27$ & $1.438 .053 .369,07$ & $4.816 .326,32$ & 1.221 .160 .5 & 4.043 .879$, \\
Non Rill & & & & & 30,93 & 80 \\
\hline
\end{tabular}

Sumber : Pengolahan Data Sekunder, 2008

Berbeda dengan pendapatan riil, pendapatan non riil nilainya jauh lebih besar. Hal ini disebabkan karena diasumsikan seluruh bibit yang dihasilkan (termasuk yang rusak) laku terjual, sehingga pendapatan non riil merupakan pendapatan yang diperoleh dari total keseluruhan bibit yang diproduksi yaitu ratarata sebanyak 712.022 batang (lihat Tabel 3). Rata-rata penerimaan non riil sebesar Rp 2.704.933.880/Ut/5bln atau sebesar Rp 9.006.103,27/Ha/5bln dan rata-rata biaya produksi sebesar Rp 1.438.053.369,07/Ut/5 bln atau sebesar Rp 4.816.326,32/Ha/5 bln, maka PTPN III Kebun Rambutan memperoleh pendapatan non riil sebesar Rp 1.221.160.530,93/Ut/5 bln atau sebesar Rp4.043.879,80/Ha/5 bln. 


\section{SIMPULAN DAN SARAN}

\section{Kesimpulan}

1) Nilai $R / C$ Ratio riil usaha pembibitan karet sebesar 1,81 dan nilai $R / C$ Ratio non riil usaha pembibitan karet sebesar 1,85. Nilai tersebut menunjukkan bahwa usaha pembibitan karet yang dikelola PTPN III tergolong efisien dan mendatangkan keuntungan. Jika masing-masing blok pembibitan menggunakan input sebesar $\operatorname{Rp}$ 1.000,- untuk usaha pembibitan maka akan diperoleh penerimaan riil yang lebih besar yakni Rp 1.810,- dan penerimaan non riil yang lebih besar yakni Rp 1.850,- dibandingkan biaya yang dikeluarkan

2) Pendapatan rill rata-rata yang diperoleh oleh PTPN III Kebun Rambutan dari usaha pembibitan karet sebesar $\mathrm{Rp} 1.116 .509 .090,93 / \mathrm{Ut} / 5$ bulan atau $\mathrm{Rp}$ $3.861 .784,88 / \mathrm{Ha} / 5$ bulan dan rata-rata pendapatan non riil adalah sebesar Rp1.221.160.530,93/Ut/5 bulan atau Rp 4.043.879,80/Ha/5 bulan. Besarnya pendapatan tersebut menunjukkan perusahaan ini tergolong sukses dalam mengelola usahanya.

\section{Saran}

Usaha pembibitan karet yang dilakukan PTPN III secara ekonomi tergolong efisien dan menghasilkan pendapatan yang tergolong besar. Oleh karena itu usaha tersebut perlu dikembangkan dan tingkatkan skala usahanya. Kemudian sebagai perusahaan yang sukses dalam mengelola usaha pembibitan karet, sebaiknya PTPN III Kebun Rambutan dapat membantu dan melakukan kemitraan dengan petani, agar dapat mengangkat perkembangan usaha petani karet yang ada disekitarnya.

\section{DAFTAR PUSTAKA}

Anonim, 2008. Harga Bibit Karet Naik : 17.500 Hektar Kebun Rakyat akan Diremajakan. http://www.kompas.com.

Anonim, 2008. Pembibitan Pohon Karet di Desa Penggalangan Potensi yang Menjanjikan. http://serdangbedagaikab.go.id.

Anonim,2008. Profil Singkat Komoditi Karet. http://regionalinvestment.com.

Semangun, 2000. Penyakit-Penyakit Tanaman Perkebunan di Indonesia. Gadjah Mada University Press. Yogyakarta.

Sihombing, 2008. Sistem Pemasaran Bibit Karet di PTPN 3. http://www.ptpn3.co.id.

Soekartawi, 2004. Agribisnis; Teori dan Aplikasinya. PT.Raja Grafindo Persada. Jakarta.

34 | Muhamad Nurung. Analisis Efisiensi dan Pendapatan Usaha Pembibitan Karet 